\title{
KRONIK
}

\section{Türkiye’de Kamu Maliyesinin Dönüşümü: 1998-2017}

Doç. Dr. Yiğit Karahanoğulları, Ankara Üniversitesi, Siyasal Bilgiler Fakültesi

3 Kasım 2002 Genel Seçimlerinin ardından tek başına iktidara gelen ve geçen süre zarfında tüm genel seçimleri kazanarak iktidarını sürdürmeyi başaran AKP, 1998 y1lında Türkiye'nin neoliberal dönüşümüne yön vermeye başlayan IMF'nin ve onun yapısal uyum programlarının ana yürütücüsü olarak Türkiye'de yeni bir kamu maliyesi inşa sürecinin de temel aktörü oldu. Bağımsız Sosyal Bilimciler Grubunun "IMF Gözetiminde On Uzun Yil" olarak adlandırdığı, Mayıs 2008 yılına kadar kesintisiz ve "tam gözetim ve denetim" altında yaşanan on yıllık IMF stand-by sürecinin büyük bölümü AKP'nin iktidarı altında yürütüldü (BSB, 2006: 12, 15).

Uluslararası finans sermayenin çıkarlarıyla uyumlu bir şekilde saydamlığı, hesap verebilirliği ve uluslararası standartlara uyumu önceleyerek başlayan bu neoliberal yeniden inşa süreci, aşama aşama yeniden şekillenmiş; kamu kesiminin borçlarını düzenli bir şekilde geri öder hale gelmesi ile, toplam borçluluğun kamudan özel kesime transferi ile, Cumhuriyet kültürünün mirası olan kamu işletmelerinin/imtiyazlarının/kaynaklarının uluslararası/ulusal sermayeye ve yeni yükselen burjuvaziye devri ile ilk etabını tamamlamıştır. Geçen süre zarfinda tek parti iktidarının siyasal gücünü konsolide etmesiyle gelinen son noktada neoliberal dönüşüm yeni anlamlar kazanmış; en açık haliyle yasama organının bütçe üzerindeki denetimi yürütme lehine neredeyse tamamen tasfiye edilmiş; bütçe hazırlık takvimi kurumlar aleyhine daraltılmış; yürütme organı, daraltılan bu takvime bile riayet etme gereği hissetmemiş; bunlardan daha da önemlisi neredeyse ülkedeki hiçbir yasaya uyma zorunluluğu olmayan bir şirket kurularak kamu varlıkları bu şirkete devredilmeye başlanmıştır. Bir zamanlar IMF ve AB'nin yürüttüğü süreçlerde tüm politikacı ve bürokratların ezberi haline getirilen "kamu kaynaklarının etkili, ekonomik ve 
verimli bir şekilde elde edilmesi ve kullanılmasını, hesap verebilirliği ve malî saydamlığ 1 sağlamak üzere..." mottosu ile başlayan AKP'nin kamu maliyesini yeniden yapılandırma süreci, anayasa değişikliği teklifi ile bütçe hakkının bütünüyle tasfiye edileceği, yani burjuva demokrasilerinin mantığına bile aykırı bir aşamaya ulaşmıştır.

Aşağıdaki derleme, bu süre zarfinda, kamu maliyesini ilgilendiren temel değişiklikleri tarihsel sırasıyla aktarmakta, gerektiğinde gazete haberleri ve köşe yazılarına referans vererek bir kamu maliyesi kroniği oluşturmaktadır. AKP'nin IMF sürecinin mirasçısı ve taşıyıcısı olduğu tespitinden hareketle, dönemsel inceleme 1998 yılından başlatılmaktadır; 2017 yılının Mart ayına kadar takip edilmektedir.

\section{AKP “Öncesi” Dönem: 1998-2002}

26 Haziran 1998, Yakın İzleme Anlaşması: Herhangi bir kredi kullanımı sağlamaksızın, Temmuz ayında uygulamaya konulup 18 aylık bir süreyi kapsayacak şekilde üçer aylık dönemlerle IMF'nin Türkiye'ye gelerek, ödemeler dengesi, dış borçlanma, özelleştirme ile sosyal güvenlik gibi yapısal reformları takip edip, uluslararası kamuoyu ile paylaşacağı bir alaşma. Makroekonomik hedefi, ödemeler dengesi sorunuyla ve enflasyonla mücadeleyle ilişkili olarak önemli mali parasal hedefler içermekte. "(...) programda maliye politikası kamu borç stokunun çevrilmesine ve/veya borçlanmanın sürdürebilirliğine odaklanmıştır. Sürdürebilirliğin sağlanması için kamu kesiminde "faiz dışı fazla" (veya kamu kesimi temel fazlası) sağlanması stratejik tercih olmuştur" (BSB, 2006: 48).

Ekonomik Politikalar Bildirgesi: Yakın İzleme Anlaşmasının ek metni. 20002002 beş alanda (bankacilık, sosyal güvenlik, tahkim, özelleştirme ve tarımsal destekleme alanlarında) 55. hükûmetin taahhüt ettiği siyasî nitelikler taşıyan kararlar yer aldi.

25 Kasım 1998, Güven Oyu: Türkbank ihalesindeki yolsuzluk iddiaları üzerine CHP'nin ANAP-DSP-DTP azınlık hükümetine dışardan verdiği desteği çekmesi ve hükümet aleyhine gensoru önergesi vermesi sonucu 25 Kasım 1998 tarihinde yapilan TBMM Genel Kurulunda, Ekonomiden Sorumlu Devlet Bakanın Güneş Taner 315 güvensizlik oyu ile ve Başbakan Mesut Yılmaz başbakanlığındaki hükümet de 314 güvensizlik oyu ile düşürüldü (TBMM, 2017). 
Ocak 1999, IMF ile Anlayış Birliği Mutabakatı: "DSP azınlık hükûmeti seçimler sonrası oluşacak hükûmetin Yakın İzleme Anlaşmasındaki hedefleri koruyacağı güvencesi” verildi (BSB, 2006: 7).

18 Nisan 1999, Erken Genel Seçimleri (Yerel Seçimlerle birleştirilerek) gerçekleştirildi. Seçim sonuçlarına göre alınan oy oranları ve kazanılan sandalye sayıları şu şekilde: DSP \%22,18 (136), MHP \%17,98 (129), FP: \%15,41 (111), ANAP: \%13,22 (86), DYP: \%12,01 (85).

\section{Mayıs 1999, DSP-MHP-ANAP Koalisyon Hükümeti}

8 Eylül 1999, İsssizlik Sigortası Kanunu: Resmi Gazetede yayımlandı.

9 Aralık 1999, Enflasyonla Mücadele Programı: IMF'ye Sunulan Niyet Mektubu ile IMF ve DB kaynakları ile desteklenecek orta vadeli bir Enflasyonla Mücadele Programı başlatıldı. Uygulamaya konulan paketin temel bileşenleri Niyet Mektubunda belirtildiği şekliyle: "programın başlangıcında kamu sektörü temel fazlasının mümkün olduğunca yüksek tutulması, yapısal reformlar ve tutarlı gelir politikaları ile desteklenmiş sıkı döviz kuru taahhütleri." Programın maliye politikası başlında belirtilen hedef ise şu şekildedir: "Enflasyon sadece kamu finansmanı sürdürülebilir bir yola sokulabilir ve artık enflasyon vergisine başvurulmaz ise ortadan kaldırılabilir. $\mathrm{Bu}$ durum, bir yandan kamu borcunun azaltılması için özelleştirmenin hızlandırılmasını, diğer yandan kamu sektörü dengesinde önemli ölçüde bir fazla yaratılmasını gerektirmektedir" (HM, 1999).

22 Aralık 1999, Stand-by: IMF ile üç y1l süreli ve 9,2 milyar SDR'lik, 17'nci stand-by anlaşması imzalandı (HM, 2017).

10 Mart 2000, Dünya Bankası'na Niyet Mektubu verildi.

22 Kasım 2000, Ekonomik Krizi: "Bu tarihte bankalararası piyasada gecelik borçlanma basit faizi yaklaşık üç kat artarak ortalama \%110.8'e, en yüksek \%210'a firladı" (Uygur, 2001).

18 Aralık 2000, IMF'ye Niyet Mektubu: "Konsolide merkezi bütçe, bütçedışı fonlar, mahalli idareler, KİT'ler, sosyal güvenlik kuruluşları, Merkez Bankası 
ve işsizlik sigortası fonunun tamamı şeklinde tanımlanan kamu sektörünün faiz dışı fazlasının güçlendirilmesi” taahhüttü verildi (HM, 2000).

30 Ocak 2001, IMF'ye Niyet Mektubu.

19-22 Şubat 2001, Ekonomik Kriz.

3 Mayls 2001, IMF'ye Niyet Mektubu.

14 Nisan 2001, Ulusal Program.

15 Mayls 2001, Güçlü Ekonomiye Geçiş Programı: Amacın, “...bir daha geri dönülmeyecek şekilde kamu yönetiminin ve ekonominin yeniden yapılandırılmasına yönelik altyapıyı oluşturmak" olduğu belirtilmiştir (BSB 2006: 54)

26 Haziran 2001, Ek Niyet Mektubu. 31 Temmuz 2001, 20 Kasım 2001, 18 Ocak 2002, 3 Nisan 2002 IMF'ye Niyet Mektuplarl

4 Şubat 2002, Stand-by: IMF ile 12,8 milyar SDR'li ve 3 y1llk süreli 18'inci stand-by anlaşması imzalandı (HM, 2017).

\section{AKP'li Yillar: 2002-2017}

3 Kasım 2002 Genel Seçimleri

Seçim sonuçlarına göre barajı geçen partilerin aldıkları oy oranları ve kazandıkları sandalye sayıları şu şekilde: AKP \%34,38 (363), CHP \%19,39 (178).

\section{Mart Ek İstikrar Tedbirleri}

"2003 Bütçesi de IMF programlarının dogmatik bir inanç düzeyinde sürdürdüğü yüzde 6.5 düzeyinde "faiz dışı fazla yaratma" saplantısını yansıtmaktadır. 3 Mart iktisadi tedbirleri ve 2003 Bütçe Tasarısı emeği ile geçinen halka yeni yükler getirirken, sermaye gelirlerini ve özellikle finansal kazançları vergi dışında tutma konusundaki ideolojik tercihi sürdürmektedir" (BSB, 2006: 55). 
5 Nisan, 25 Temmuz, 31 Ekim 2003 Niyet Mektupları

Sırasıyla 4, 5 ve 6'ncı gözden geçirmeye ilişkin niyet mektupları.

\section{Aralık 2003, Kamu Mali Yönetimi ve Kontrol Kanunu}

10 Aralık 2003 tarihinde kabul TBMM tarafindan kabul edilen 5018 Say1lı Kamu Mali Yönetimi ve Kontrol Kanunu, 24 Aralık’ta Resmi Gazetede yayımland.

Yasanın amaç maddesi şu şekildedir: "Bu Kanunun amacı, kalkınma planları ve programlarda yer alan politika ve hedefler doğrultusunda kamu kaynaklarının etkili, ekonomik ve verimli bir şekilde elde edilmesi ve kullanılmasını, hesap verebilirliği ve malî saydamlığı sağlamak üzere, kamu malî yönetiminin yapısını ve işleyişini, kamu bütçelerinin hazırlanmasını, uygulanmasını, tüm malî işlemlerin muhasebeleștirilmesini, raporlanmasını ve malî kontrolü düzenlemektir."

"Kamu mali yönetiminde yürütülen reform çalışmaları kapsamında, kamu maliyesinde saydamlık ve hesap verilebilirliğin artırılması, stratejik planlama ve performansı esas alan çok yıllı bütçelemeye geçilmesi, bütçenin kapsamının genişletilmesi, iç kontrol ve diş denetim sistemlerinin Avrupa Birliği standartlarına uygun hale getirilmesi ile kamu idarelerinin mali yönetim alanındaki inisiyatiflerinin genişletilmesini hedefleyen 5018 sayılı Kamu Mali Yönetimi ve Kontrol Kanunu, 10/12/2003 tarihinde Türkiye Büyük Millet Meclisi tarafından kabul edilmiştir" (OVMP, 2006).

\section{Ocak 2004 Analitik Bütçe}

"Konsolide bütçe kapsamındaki kurum ve kuruluşların 2004 Yılı Bütçeleri Analitik Bütçe Sınıflandırmasına göre hazırlanarak kanunlaşmış ve 01.01.2004 tarihinden itibaren yürürlüğe girmiştir” (MB, 2004: 7).

"Analitik bütçe sınıflandırmasının test edilebilmesi için Enerji ve Tabii Kaynaklar Bakanlığı, Hazine Müsteşarlığı, Sahil Güvenlik Komutanlığı, Karayolları Genel Müdürlüğü ile Hacettepe ve Ege Üniversiteleri pilot kuruluş olarak seçilerek bu kuruluşların 2002 yılı bütçeleri yeni bütçe kodlaması sistematiğine uygun olarak hazırlanmış ve 2002 yılı Ocak ayından itibaren de mevcut kod yapısına paralel olarak uygulama başlatılmıştır. 2003 yılı bütçe hazırlık süreci öncesinde verilen eğitim seminerleri neticesinde, bu altı kuruluş dışındaki diğer genel bütçeye dahil daireler ve katma bütçeli idarelerin analitik bütçe sınıflandırmasına uygun bütçelerini de hazırlamaları ve seçilen bir birimlerinde paralel uygulama yürütmeleriyle birlikte analitik bütçe sınıflandırması uygulaması yaygınlaştırılmıştır” (MB, 2004: 7). 
28 Mart 2004 Yerel Seçimler

2 Nisan 2004 Yedinci Gözden Geçirmeye Illişkin Niyet Mektubu

10 Temmuz 2004 Büyükşsehir Belediyesi Kanunu

10 Temmuz 2004'te kabul edilen 5216 Sayılı Büyükşehir Belediyesi Kanunu 23 Temmuz 2004'te Resmi Gazetede yayımlandı. Bir sonraki yıl kanunda değişiklik yapıldı. 2 Temmuz 2005'te kabul edilen 5390 sayılı Büyükşehir Belediyesi Kanununda Değişiklik Yapılmasına Dair Kanun 13 Temmuz 2005 'te Resmi Gazetede yayımlandi.

15 Temmuz 2004, 26 Nisan 2005 Niyet Mektupları

5 Mayıs 2005 Gelir İdaresi Başkanlı̆̆ı’nın Teşkilat ve Görevleri Hakkında Kanun

“5345 Sayılı Gelir İdaresi Başkanlığı’nın Teşkilat ve Görevleri Hakkında Kanun” 16 Mayıs 2005'te Resmi Gazetede yayımlanarak yürürlüğe girmiş̧tir.

11 Mayls 2005, Stand-by Anlaşması

IMF ile 6,6 milyar SDR'li, 19'uncu Stand-by anlaşması imzalandı.

\section{Teтmuz 2005 Belediye Kanunu}

3 Temmuz 2005'te kabul edilen 5393 sayılı Belediye kanunu 13 Temmuz 2005 'te Resmi Gazetede yayımland. Daha önce 7 Aralık 2004'te kabul edilen 5272 sayılı Belediye Kanununu 18 Ocak 2005 tarihli kararı ile Anayasa Mahkemesi iptal etmişti.

\section{Eylül 2005 Tüpraş’ın Özelleştirilmesi}

12 Eylül 2005 tarihinde Tüpraş'ın $\% 51$ oranında hissesi için ihale gerçekleştirildi. 4 milyar 140 milyon dolar karşılığında Koç-Shell Ortak Girişim Grubuna satıldı. Devir işlemleri 26 Ocak 2006'da tamamlanarak Tüpraş'ın çoğunluk hisselerinin sahibi Enerji Yatırım A.Ş. oldu (ÖİB, 2007). 
4 Ekim 2005 Erdemir'in Özelleştirilmesi

4 Ekim 2005 tarihinde gerçekleştirilen ihale sonucu Erdemir'in \%46,12 oranındaki hissesinin 2 milyar 770 milyon OYAK'a satılması kararlaştııldd. 27 Şubat 2006 tarihinde hisse satış sözleşmesi gerçekleştirildi (ÖİB 2007).

\section{Ekim 2005 Anayasa Değişikliği}

29 Ekim 2005'te kabul edilen ve 9 Kasım 2005'te Resmi Gazetede yayımlanarak yürürlüğe giren Türkiye Cumhuriyeti Anayasasının Bazı Maddelerinin Değiştirilmesi Hakkında Kanun ile, Anayasadaki "genel ve katma bütçelerle" ibareleri "merkezî yönetim bütçesiyle" şeklinde değiştirildi; 160'ıncı maddeye, "mahallî idarelerin hesap ve işlemlerinin denetimi ve kesin hükme bağlanması Sayıştay tarafından yapılır" fıkrası eklendi.

Anayasa değişikliklerine ilişkin Bağımsız Sosyal Bilimcilerin görüşleri şu şekildedir: "Ekim 2005 tarih ve 5428 Sayılı Kanun'un öngördüğü değişiklikler, Kamu Mali Yönetim ve Kontrol Kanunu ve bu kanunun ek ve değişiklikleri ile hem terim ve tanımlarda, hem de özde uyum sağlamak üzere gerçekleştirilmiş; bir anlamda kanunlar Anayasa'ya değil, Anayasa kanunlara uydurulmuştur. 5428 Sayılı Kanun'un getirdiği dikkat çekici ve önemli bir değişiklik, yerel yönetimlerin mali denetiminin Sayıştay'a bırakılmasıdır. 5428 sayılı Kanunun getirdiği bir değişiklik de "yerel yönetimlerin hesap ve işlemlerinin denetimi ve kesin hükme bağlanmasını" Anayasa ile verilmiş bir göreve dönüştürülmesidir. Ancak, zaten yerel yönetimleri denetleme yetkisi olan Sayıştay'ın yeni kanun teklifine konulan hükümler gereğince bunu özel denetim kuruluşlarına yaptırma yetkisiyle donatılmış olmasının, Anayasa'nın 128. maddesinin "kamu hizmetleri memurlar ve diğer kamu görevlileri eliyle yürütülür" hükmüne açık bir istisna oluşturduğuna dikkat çekmek gerekir" (BSB 2006: 64).

\section{Aralı 2005 TOKI, TRT, TMSF 5018'in Kapsamından Çıkarıldı}

22 Aralık 2005'te kabul edilen 5436 Sayılı "Kamu Mali Yönetimi ve Kontrol Kanunu ile Bazı Kanun ve Kanun Hükmünde Kararnamelerde Değişiklik Yapılması Hakkında Kanun" 24 Aralık'ta Resmi Gazetede yayımlandı ve ilk maddesi dışında 01 Ocak 2006'da yürürlüğe girdi. Böylece 1927 y1lından itibaren yürürlükte olan 1050 sayılı Muhasebe-i Umumiye Kanunu yürürlükten kaldırıldı.

5436 sayılı Kanunun getirdiği asıl önemli düzenleme ise TOKİ, TRT, TMSF, Spor Toto Genel Müdürlüğü, Milli Piyango İdaresinin de bulunduğu 29 kurumun, Kanun kapsamından çıkarılması oldu. Dolayısıyla bu kurumlar Sayıştay denetiminin de dışına çıkarıldı. İlerleyen yıllarda Türkiye'nin yapısal 
dönüşümünde önemli ekonomik ve siyasi işlevleri olacak olan bu kurumlar, daha 5018 yürürlüğe girmeden, TBMM denetiminden çıkarılmış oldu.

\section{Temmuz 2005 Türk Telekom'un Özelleştirilmesi}

1 Temmuz 2005 tarihinde Türk Telekom'un \%55 hissesi için ihale yapıld 1 ve Suudi merkezli, Oger Telecoms Ortak Girişim Grubu'na 6 milyar 550 milyon dolara satışı gerçekleşti. Hisse devir işlemleri 14 Kasım 2005'te tamamlandı (ÖİB, 2007).

\section{Kasim 2005 IMF'ye Niyet Mektubu}

\section{Ocak 2006, Illk Çok Yıllı Bütçe}

5018' in yürürlüğe girmesiyle ilk çok yıllı bütçe uygulamasına başlanmış oldu.

\section{Mayls 2006 Sosyal Güvenlik Kurumu Kanuпu}

16 Mayıs 2006 tahinden kabul edilen ve 20 Mayıs 2006'da Resmi Gazetede yayımlanan Sosyal Güvenlik Kurumu Kanunu ile TC Emekli Sandığı, Sosyal Sigortalar Kurumu ve Bağ-Kur tek çatı altında toplayan Sosyal Güvenlik Kurumu kuruldu.

\section{Haziran 2006 Sosyal Sigortalar ve Genel Sağlık Sigortası Kanunu}

31 Mayıs 2006'da kabul edilen 5510 sayılı Sosyal Sigortalar ve Genel Sağl1k Sigortası Kanunu 16 Haziran 2006'da Resmi Gazetede yayımland.

7 Temmuz 2006 IMF'ye Niyet Mektubu

27 Kasım 2006 IMF'ye Niyet Mektubu

\section{1 Şubat 2007 Konut Finansmani, Mortgage Sisteminin Kurulması}

21 Şubat 2007 tarihinde kabul edilen, 6 Mart 2007'de Resmi Gazetede yayımlanan 5582 sayılı Konut Finansmanı Sistemine İliş̧kin Çeşitli Kanunlarda Değişiklik Yapılması Hakkında Kanun ile yapılmış olan düzenleme sonucunda, finansal kiralama şirketleri, finansman şirketleri ve yatırım bankalarına gerekli düzenlemelerin yapılmasını müteakip, mevduat toplamaksızın sermaye piyasasından elde ettikleri fonları tüketicilere kullandırmak imkanı 
verilmiştir." "İpotek finansman kuruluşlarının amacı kredi veren kuruluşlara fon yaratmak olup, bu kuruluşlar tüketiciye doğrudan kredi vermezler" (Akkaya, 2011). Temel amacı gayrimenkul piyasasını uluslararası fonlara açmak olan bu yasaya ilişkin Bağımsız Sosyal Bilimcilerin yorumu şu şekildedir: 'Kısaca 'borç-konut sistemi' olarak adlandırılabilecek bir model getiren 5582 Sayıl Kanun'un temel toplumsal işlevi, 'seçimler yılı' olan 2007'de düşük gelir gruplarının konut sahibi olma özlemlerini canlı tutmaktır. Ancak getirisi yüksek ve riski düşük yatırım alanları peşindeki yabancı emeklilik fonlarını çekmeye ve mali sistemde yer alan yerli-yabancı kuruluşların çıkarlarını güvence altına almaya verilen önem, kanun tasarısının genel gerekçesinde açıç̧a ortaya konulmuştur. Yukarıda değinilen Dönüşüm Alanları Kanun Tasarısı ile birlikte ele alındığında bu kanun AKP'nin kentsel rantları yönlendirme ve üleştirme çabalarının tamamlayıcı bir öğesidir" (BSB, 2008: 313).

\section{Nisan 2007 Asgari Geçim İndirimi ile Vergi İadesinin Kaldırılması}

28 Mart 2007'de kabul edilen 5615 sayılı Gelir Vergisi Kanunu ve Bazı Kanunlarda Değişiklik Yapılmasına Dair Kanun 4 Nisan 2007'de Resmi Gazetede yayımlandı. Kanunun 2'nci Maddesi ile Asgari Geçim İndirimi uygulaması düzenlendi:

"Ücretin gerçek usûlde vergilendirilmesinde asgarî geçim indirimi uygulanır.

Asgarî geçim indirimi; ücretin elde edildiği takvim yılı başında geçerli olan ve sanayi kesiminde çalışan 16 yaşından büyük işçiler için uygulanan asgarî ücretin yıllık brüt tutarının; mükellefin kendisi için \% 50'si, çalışmayan ve herhangi bir geliri olmayan eşi için \% 10'u, çocukların her biri için ayrı ayrı olmak üzere; ilk iki çocuk için \% 7,5 diğer çocuklar için \% 5'idir. Gelirin kısmî döneme ait olması halinde, ay kesirleri tam ay sayılmak suretiyle bu süreye isabet eden indirim tutarları esas alınır. Asgarî geçim indirimi, bu fikraya göre belirlenen tutar ile 103 üncü maddedeki gelir vergisi tarifesinin birinci gelir dilimine uygulanan oranın çarpılmasıyla bulunan tutarın, hesaplanan vergiden mahsup edilmesi suretiyle uygulanır. Mahsup edilecek kısmin fazla olması halinde iade yapilmaz.

İndirimin uygulamasında 'çocuk' tabiri, mükellefle birlikte oturan veya mükellef tarafından bakılan (nafaka verilenler, evlat edinilenler ile ana veya babasını kaybetmiş torunlardan mükellefle birlikte oturanlar dâhil) 18 yaşını veya tahsilde olup 25 yaşını doldurmamış çocukları, 'eş' tabiri ise, aralarında yasal evlilik bağ 1 bulunan kişileri ifade eder.

İndirim tutarının tespitinde mükellefin, gelirin elde edildiği tarihteki medenî hali ve aile durumu esas alınır. İndirim, yukarıdaki oranlara göre hesaplanan tutarları aşmamak kaydıyla, ücret geliri elde eden aile fertlerinden her biri için ayrı ayrı, çocuklar için eşlerden yalnızca birisinin gelirine uygulanır. 
Boşananlar için indirim tutarının hesabında, nafakasını sağladıkları çocuk sayısı dikkate alınır.

Bakanlar Kurulu, indirim konusu yapılacak toplam tutarın asgarî ücretin yıllık brüt tutarını aşmaması şartıyla ikinci fikrada belirtilen asgarî geçim indirimi oranlarını artırmaya veya kanunî oranına kadar indirmeye yetkilidir.

Asgarî geçim indiriminin uygulama dönemleri ve mahsup şekli ile diğer hususlara ilişkin usûl ve esaslar Maliye Bakanlığınca belirlenir."

1 Ocak 2008'den itibaren elde edilen gelirler için uygulanacak olan asgari geçim indirimi düzenlemesi ile 1985 'ten beri uygulanmakta olan vergi iadesi kaldırılmış oldu. Vergi iadesinin kaldırılmasının kayıtdışılığı körükleyeceğini konusunda eleştirel getirildi.

\section{Mayls 2007 IMF'ye Niyet Mektubu}

\section{Mayls 2007 KEY'in Tasfiyesi}

5664 Sayılı Kanun ile Konut Edindirme Yardımı Hak Sahiplerine Ödeme Yapılmasına Dair Kanun ile KEY hesapları tasfiye edildi.

Hak sahiplerine nakit veya hisse senedi olarak yapılacak ödemelere ilişkin usul ve esasları düzenlemek için çıkarılan Konut Edindirme Yardımı Hak Sahiplerine Ödeme Yapılmasına Dair Yönetmelik14 Ağustos 2007'de Resmi Gazetede yayımlanandı.

\section{Temmuz 2007 PETKIM'in Özelleştirilmesi}

5 Temmuz 2007'de Petkim'in \%51'lik hisseleri için ihale gerçekleştirildi. 2,040 milyar dolara ikinci en yüksek teklifi veren Socar-Turcas-İnjaz Ortak Girişim Grubu'na satıldı (ÖİB, 2008: 38).

En yüksek teklifi 2 milyar 50 milyon dolara TransCentralAsia Ortak Girişim Grubu vermesine rağmen Rekabet Kurumu tarafindan da uygun bulunması ile ihalede 10 milyon dolara daha düşük teklif veren Socar-Turcas-Injaz Ortak Girişim Grubu'na satış gerçekleştirilmiş oldu.

\section{Temmuz 2007 Genel Seçimleri}

Seçim sonuçlarına göre barajı geçen partilerin aldıkları oy oranları ve kazandıkları sandalye sayıları şu şekilde: AKP \%46,58 (341), CHP \%20,88 (112), MHP \% 14,27 (71). 


\section{Nisan 2008 IMF'ye Niyet Mektubu}

"Gelirleri artırmak amacıyla; akaryakıt ve tütün ürünlerine uygulanan maktu vergilerin ayarlanması ile gelir idaresinin güçlendirilmesi de dahil olmak üzere, birtakım tedbirler alınmıştır. Ayrıca, her ne kadar gelir hedeflerine ulaşılacağına dair inancımız tam olsa da; gelirlerin tahminlerin altında kalması ya da -kamu iktisadi teşebbüslerinin fiyatlamalarına ilişkin olanlar da dahil olmak üzerediğer bütçe varsayımlarının gerçekleşmemesi halinde, ilave tedbirler uygulamaya konulacaktır. Harcamaların, GSYH'ye oran olarak, 2007 yı1ı gerçekleşmelerine göre bir miktar daha düşük kalması beklenmektedir. Personel harcamalarının kontrol altına alınması amacıyla yeni memur alımlarına getirilen (devlet memuriyetinden ayrilanların en fazla \%50'si kadar yeni memur istihdam edilmesi yönündeki) sınırlamalara riayet edilmiştir" (HM, 2008: 4-5).

\section{7 Şubat 2008 Bazı Kamu Alacaklarının Uzlaşma Usulü ile Tahsili}

20 Şubat 2008 tarihinde kabul edilen ve 27 Şubat 2007 tarihinde Resmi Gazetede yayımlanan 5736 sayılı Bazı Kamu Alacaklarının Uzlaşma Usulü ile Tahsili Hakkında Kanun.

\section{Mayıs 2008 İşsizlik Sigortası Fonunda İlk Gedik}

15 Mayıs 2008'de kabul edilen 5763 sayılı İş Kanunu ve Bazı Kanunlarda Değişiklik Yapılması Hakkında Kanunun 19'uncu maddesi ile 4447 sayı1ı İşizlik Sigortası Kanununa şu geçici madde eklendi:

"Geçiçi Madde 6 - a) 2008 yılına münhasır olmak üzere, Fonun mevcut nema gelirlerinden 1.300.000.000 YTL'lik kısım Fon tarafindan Hazine İç Ödemeler Muhasebe Birimi hesaplarına aktarılır ve genel bütçenin (B) işaretli cetveline gelir kaydedilir. Kaydedilen bu tutarları, Yüksek Planlama Kurulu kararına istinaden Güneydoğu Anadolu Projesi kapsamındaki yatırımlara öncelik vermek kaydıyla münhasıran ekonomik kalkınma ve sosyal gelişmeye yönelik yatırımlarda kullanılmak üzere ilgili idare bütçelerine ödenek kaydetmeye Maliye Bakanı yetkilidir. Bu ödenekler, 2008 yılı yatırım programı ile ilişkilendirilir.

b) 2009-2012 yıllarında Fon tarafından tahsil edilecek nema gelirlerinin dörtte biri, ilgili yıl genel bütçelerinin (B) işaretli cetvelinde bütçe gelir tahmini olarak yer alır. İlgili yıl bütçeleri hazırlanırken Güneydoğu Anadolu Projesi kapsamındaki yatırımlara öncelik vermek kaydıyla münhasıran bölgesel ekonomik kalkınma ve sosyal gelişmeye yönelik yatırımların finansmanı için ilgili idare bütçelerine bu gelir tahmini karşılığ kadar ödenek öngörülür. Bu gelirler, Fon tarafindan tahsil edilen ayı izleyen ayın 15'ine kadar Hazine İç 
Ödemeler Muhasebe Birimi hesaplarına aktarılır ve yılı genel bütçesinin (B) işaretli cetveline gelir kaydedilir.

c) Bu madde kapsamında aktarılacak kaynakla gerçekleştirilecek yatırımlardan elde edilecek getiriler ile varlık satışlarından elde edilecek gelirlerin Yüksek Planlama Kurulunca belirlenecek oranı, kullanılan kaynak tutarını aşmamak kaydıyla Fona aktarılır.

$\mathrm{Bu}$ maddenin uygulanmasına ilişkin usul ve esaslar Çalışma ve Sosyal Güvenlik Bakanlığı ile Hazine Müsteşarlığı tarafından müştereken belirlenir.”

Uğur Gürses'in yorumu şu şekilde: "İşsizlik sigortası fonu, açılan deliklerle kevgire dönmeye aday. Üç yılda 10 milyar harcand1. 2008'de yatırımlara para aktarma bahanesiyle başlayan süreç devam ediyor. Çıkarılan yasa ile işsizlik sigortas1 fonunun dönemsel nemasindan 2008 y1lında 1,3 milyar TL aktarma kararı alınmıştı. 2009-2012 yıllarında ise fon tarafından tahsil edilecek nema gelirlerinin dörtte biri, başta GAP öncelikli olmak üzere yatırımlara aktarılmak üzere bütçeye gelir yazılacaktı. Burada kalmadı, her yıl yapılan değişikliklerle işsizlik fonunun nemalarını 'Daha fazla nasıl bütçeye gelir kaydederiz?' girişimleri başarıyla uygulandı" (Gürses, 2010).

$\mathrm{Bu}$ eleştirileri haklı çıkararak, ilerleyen yıllarda fonun kullanımı, işçiden çok işveren ve devlete yarayacak şekilde devam etti. Oğuz Oyan'ın 2016 yllında yaptığ1 yorum şu şekilde: "Haziran 2000 ile Kasım 2016 arasında bu fonun anapara ve nema gelirleri toplamı 148,9 milyar liraya ulaşmış. (Teşviklere bağlı olarak işverenden tahsil edilmeyen pirim kesintileri bu rakam içine dahil değil). Kasım 2016 sonu itibariyle İSF'nun kasasında duran toplam fon varlığ (fon bakiyesi) ise 102,0 milyar TL. Demek ki Fonun 46,9 milyar TL'si harcanmış. Peki işsizlere mi? İşsizlik sigortası ödenekleri (ISÖ) kapsamında şimdiye kadar işsizlere 13,9 milyar TL ödeme yapılmış. Demek ki toplam fon girişlerinin (fon kaynağının) yüzde 10 'u bile değil. (13,9:148,9=yüzde 9,3 eder). Peki kalanı? 2008-2013 döneminde Fondan bütçeye yapılan aktarmalar da 13 milyar TL'yi bulmuş." "2013'ten sonra bütçeye aktarmalar sonlandırıldı ama yeni bir gider kapısı açıldı. Aktif İşgücü Programları (AİP) denilen bir geçici istihdam yaratma (veya yaratıyormuş gibi yapma) programına 2014'ten itibaren aktarılan kaynaklar gittikçe büyümeye başlamış. $\mathrm{Bu}$ programa 2014'te 1 milyar 358 milyon TL aktarılırken, bu miktar 2015'te 3 milyar 26 milyona, 2016'nın ilk 11 ayında ise 6 milyar 98 milyona çıkıvermiş." "Fondan 16 yıl 5 ay zarfinda 46,9 milyar harcanmış demiştik. Bunun 13,9'u işsize, 13'ü devlete, 10,5'i de AİP'ye" (Oyan, 2016a). 


\section{Mart 2009 Yerel Seçimler}

\section{Nisan 2010 Sukuk Piyasasının Kuruluşu}

İslam hukukuna göre tasarlanan menkul kıymetlerin genel adı olan Sukuk, Türkiye'ye Sermaye Piyasası Kurulunun, Kira Sertifikaları ile ilgili 1 Nisan 2010 tarihinde yayımladığı tebliğ ile girdi.

Özel sektör şirketlerinin, kamu kuruluşlarının, özel/kamu bankalarının, belediyelerın ve devletin çıkarabileceği bu sukuklar, SPK kanununda sermaye piyasası aracisı olarak tanımland1.

Sadece özel kesimin değil devletin de Asya ve Ortadoğu'daki İslami sermayeden borçlanabilmesi mümkün hale getirildi; kamu kesimi bu konuda öncü oldu (KTP, 2017).

Hazine Müsteşarlığı, ilk sukuk ihracını, farklı vadelerde olmak üzere toplam 3 milyar dolarlık tutarla 26 Eylül 2012 tarihinde gerçekleştirdi (KTP, 2017).

\section{Aralık 2010 Sayıştay Kanunu}

3 Aralık 2010 tarihinde kabul edilen 6085 Sayılı Sayıştay Kanunu 19 Aralık 2010 tarihinde Resmi Gazetede yayımland.

"Sayıştay tarafından gerçekleştirilen performans denetimleri mali ve hukuki sorumluluk doğurmaz" hükmü ile performans denetimlerinin bağlayıcılığı ortadan kaldırıldı. Sayıştay'ın denetim alanı içerisine askeri kurumlar, mahalli idarelerin şirketleri de girdi.

\section{Mayls 2010 Mali Kural Kanun Tasarlst}

İlerleyen aylarda yasalaşma süreci ertelenen ve nihayetinde de rafa kaldırılan Mali Kural Kanun Tasarısı, TMBB Plan ve Bütçe Komisyonunda kabul edildi.

Bütçe hedeflerinin belirli bir matematik formülasyonuyla belirlenmesini öngören bu yasal düzenleme, hükümetlerin bütçe fazlası vermesini teknik ve yasal bir zorunluluk haline getirmekte ve uluslararası piyasalara borç geri ödemelerinin garanti altına olduğunu göstermeyi öngörmekte.

Ali Babacan: "Türkiye'nin gelecek 10 yıla dönük büyüme, bütçe açığı, borcun GSMH'ye oranı gibi makro dengeleriyle ilgili hedeflerini yasayla ortaya koyacağız. Hem kendimizi, hem de gelecek hükümetleri bağlamış olacağız. Hükümetleri cendereye sokmadan, çocuklarımız, torunlarımız için öngörülebilir bir Türkiye ekonomisi ortamı yaratmaya çalışıyoruz. Ortaya koyacağımız Mali Kural'1 değiştirmeye kimse cesaret edemez" (Munyar, 2010).

Mali Kural daha yasalaşmadan 2010-2012 OVP'ye de girdi: "Mali kurala ilişkin yasal altyapının en geç 2010 yılının ilk çeyreğinde tamamlanması 
hedeflenmektedir. 2011 yılı bütçe döneminden itibaren kamu mali yönetimi, belirlenen mali kural ile uyumlu olarak yürütülecektir. Kuralın uygulanması, izlenmesi ve kontrolüne ilişkin olarak kamu malî yönetim sisteminde gerekli iyileştirmeler 2010 yılında yapılacaktır"(OVP, 2009: 4).

"Mali Bakan Şimşek, "mali kural yasasına ilişkin çalışmalar bu döneme yetişmiyor, daha sonraki dönemlerde tabii ki değerlendirilir" dedi (Hürriyet, 2010).

Yaz döneminde, AKP TBMM'de takvim çok sıkışık diye yeni yasama dönemine ertelendi. Ardından rafa kaldırıldı (Munyar, 2010).

\section{8 Şubat 2011 İller Bankası Yerine İlbank'ın Kurulması}

26 Ocak 2011 tarihinde kabul edilen ve 8 Şubat 2011 tarihinde Resmi Gazetede yayımlanan 6107 sayılı İller Bankası Anonim Şirketi Hakkında Kanun isimli kanun ile "özel hukuk hükümlerine tabi, tüzel kişiliğe sahip, anonim şirket statüsünde "İller Bankası Anonim Şirketi" unvanıyla bir kalkınma ve yatırım bankası kurulmuş" ve ismi İlbank olarak kısaltılmıştır.

"iller Bankası, belediyelerin bu tür gereksinmelerini karşılamak amaciyla kurulmuştu. Adı banka olmasına karşın bankacılık yapmıyor, kamu hizmetinin görülebilmesi için belediyelere finansal destek sağlıyordu. 2011 y1lında İlbank adı verilerek bir anonim şirkete dönüştürüldü. Banka artık, ticari bankacılığın gereklerince çalışmak zorunda. Bu nedenle de, kredi kararlarını verirken, halkın gerçek gereksinmelerini değil, belediyelerin verecekleri ödeme planlarını değerlendiriyor. Belediyeler, devlet eliyle piyasaya yönelmek zorunda birakıllyorlar" (Sev, 2016a).

\section{Haziran 2011 Genel Seçimleri}

Seçim sonuçlarına göre barajı geçen partilerin ve meclise giren toplam bağımsız milletvekillerinin aldıkları oy oranları ve kazandıkları sandalye sayıları şu şekilde: AKP \%49,83 (327), CHP \%25,98 (135), MHP \%13,01 (53), Bağımsızlar \%6,57 (35).

\section{Ağustos 2011 Bütçe Takviminde Değişiklik}

26/9/2011 tarihli ve 659 sayılı KHK'nın (Genel Bütçe Kapsamındaki Kamu İdareleri ve Özel Bütçeli İdarelerde Hukuk Hizmetlerinin Yürütülmesine İlişkin Kanun Hükmünde Kararname) 17'nci maddesiyle, 5018 say1lı kanununda şu değişiklikler yapıldı:

"a) $16 \mathrm{nc}$ maddesinin ikinci fikrasında yer alan "Mayıs ayının sonuna kadar" ibaresi "en geç Eylül ayının ilk haftası sonuna kadar" şeklinde, üçüncü 
fikrasında yer alan "Haziran” ibaresi “en geç Eylül” şeklinde ve dördüncü fikrasında yer alan "Haziran ayının sonuna kadar" ibaresi "en geç Eylül ayının onbeşine kadar" şeklinde değiştirilmiştir.

b) 17 nci maddesinin dördüncü fikrasında yer alan "Temmuz" ibaresi "en geç Eylül" şeklinde değiştirilmiştir."

Böylece bütçenin hazırlanma süreci sıkışık bir takvime mahkum edildi. Kısa bir süre sonra, bu daraltılmış yasal takvim bile ihlal edilerek, bütçe hazırlıkları bir aşama daha da sıkıştırıldı; bu fiili durum, olağan bir hal aldı. OVP ve OVMP'nin hangi tarihlerde çıkarıldığı, yazının ek bölümünde tablo şeklinde sunulmaktadır.

\section{Mart 2014 Yerel Seçimler}

\section{Eylül 2014 Belediye Mallarının Haczine İlişkin Düzenleme}

Belediye Yasasının 15. maddesine, 10 Eylül 2014 tarihinde aşağıdaki fikra eklendi: "İcra dairesince haciz kararı alınmadan önce belediyeden borca yeter miktarda haczedilebilecek mal gösterilmesi istenir (...) . On gün içinde yeterli mal beyan edilmemesi durumunda yapılacak haciz işlemi, alacak miktarını aşacak (...) şekilde yapılamaz."

Fıkranın ilk halinde "...icra dairelerince haciz kararı alınmadan önce belediyeden borca yeter miktarda haczedilecek mal göstermesi istenmesi öngörülmüştü. Fıkraya göre, belediyenin gösterdiği dışında bir başka taşınmaz haciz edilemeyecekti. Fıkrayla ayrıca kamu hizmetini aksatacak şekilde haciz yapılamayacağ da öngörülüyordu."

Anayasa Mahkemesi'nin 17/6/2015 tarihli ve E.: 2014/194, K.: 2015/55 say1lı Kararı ile bu fikranın birinci cümlesinde yer alan "...ve haciz işlemi sadece gösterilen bu mal üzerine uygulanır" ibaresi ile aynı fikranın ikinci cümlesinde yer alan “ ...veya kamu hizmetlerini aksatacak ...” ibaresi iptal edilmiştir (5393 Belediye Kanunu Madde 15, dipnot 2).

"Bu iki kuralı anayasa Mahkemesi 'anayasayla öngörülen hukuk devleti ilkesine, hak arama özgürlügüne, mahkemeye erişim, mülk edinme ve miras haklarına aykırı olduğu' gerekçesiyle iptal etti. Bu iptal kararından sonra icra dairesi, gözüne kestirdiği belediye taşınmazlarını, kamu hizmetini aksatır mı, aksatmaz mı düşüncesi taşımadan haciz edebilecek" (Sev, 2016a).

\section{Mart 2015 Örtülü Ödenek Cumhurbaşkanına Genişletilmesi}

27/3/2015 tarihli ve 6639 say1l Kanunun 39'uncu maddesiyle, 5018 say1l yasanın 24'üncü maddesinde yer alan "Hükümet icapları" ibaresi "Devlet ve 
Hükümet icapları" şeklinde, "Başbakanlık bütçesine" ibaresi "Cumhurbaşkanlığı ve Başbakanlık bütçelerine" şeklinde ve "Başbakanın ve ailesinin" ibaresi "Cumhurbaşkanının, Başbakanın ve ailelerinin" şeklinde değiştirildi. İlgili maddenin son hali şu şekilde: "Örtülü ödenek; kapalı istihbarat ve kapalı savunma hizmetleri, Devletin millî güvenliği ve yüksek menfaatleri ile Devlet itibarının gerekleri, siyasi, sosyal ve kültürel amaçlar ve olağanüstü hizmetlerle ilgili Devlet ve Hükümet icapları için kullanılmak üzere Cumhurbaşkanlığı ve Başbakanlık bütçelerine konulan ödenektir. Kanunlarla verilen görevlerin gerektirdiği istihbarat hizmetlerini yürüten diğer kamu idarelerinin bütçelerine de örtülü ödenek konulabilir. Örtülü ödenek, bu amaçlar dışında ve Cumhurbaşkanının, Başbakanın ve ailelerinin kişisel harcamaları ile siyasi partilerin idare, propaganda ve seçim ihtiyaçlarında kullanılamaz. İlgili yılda bu amaçla tahsis edilen ödenekler toplamı, genel bütçe başlangıç ödenekleri toplamının binde beşini geçemez."

"Anayasaya aykırı olduğu gerekçesiyle büyük tartışmalara yol açan bu yasa değişikliği, örtülü ödeneğin Cumhurbaşkanı ile Başbakan arasında hangi oranlarda kullanılacağı konusuna açıklık getirmiyor" (Toker, 2016).

2015 'te 1,773 milyar TL. 2014 'te 1,078 milyar TL. 2013'te 1,248 milyar TL. 2012 'de 1,175 milyar TL. 2011 'de 0,951 milyar TL. 2010 'da 0,706 milyar TL. 2009 'da 0,634 milyar TL. 2008 'de 0,510 milyar TL. 2007 'de 0,436 milyar TL. 2006 'da 0,327 milyar TL. 2005 'te 0,156 milyar TL. 2004 'te 0,107 milyar TL. 2003 'te 0,103 milyar TL TL (Toker, 2016).

\section{Haziran 2015 Genel Seçimleri}

Seçim sonuçlarına göre barajı geçen partilerin aldıkları oy oranları ve kazandıkları sandalye sayıları şu şekilde: AKP \%40,87 (258), CHP \%24,95 (132), MHP \% 16,29 (80), HDP \%13,12 (80).

\section{Kasım 2015 Genel Seçimleri}

Seçim sonuçlarına göre barajı geçen partilerin aldıkları oy oranları ve kazandıkları sandalye sayıları şu şekilde: AKP \%49,50 (317), CHP \%25,32 (134), MHP \%11,90 (40), HDP \%10,76 (59)

\section{Aralık 2015 Geçici Bütçe Kanunu}

"Merkezi Yönetim Bütçesinin hazırlık sürecini başlatan ve 2016-2018 dönemini kapsayan 'Orta Vadeli Program (OVP)' 11 Ekim 2015 tarih ve 29499 sayılı Resmi Gazetede yayımlanmıştır. Bu Program çerçevesinde hazırlanan 2016 Yılı Merkezi Yönetim Bütçe Kanun Tasarısı TBMM'ne gönderilmiştir. Ancak, 1 Kasım 2015 tarihinde gerçekleştirilen Genel Seçim nedeniyle 2016 
Y1lı Merkezi Yönetim Bütçe Kanunu'nun TBMM'nde görüşülmesi ve yasalaşması mümkün olmamıştır.

Genel Seçim sonrasında yeni hükümetin kurulmasıyla birlikte yasal süreç için yeterli süre kalmadığından 2016 Yı1ı Merkezi Yönetim Geçici Bütçe Kanunu 23 Aralık 2015 tarih ve 29571 sayılı Resmi Gazetede yayımlanarak yürürlüğe girmiştir" (OVP 2016-2018).

6654 say1lı 2016 Yılı Merkezi Yönetim Geçici Bütçe Kanununun ilk maddesi, (I), (II) ve (III) sayıl1 cetvellerde yer alan kurumlara 1/1/2016 tarihinden 31/3/2016 tarihine kadar geçecek üç aylık dönemde, 22/12/2014 tarihli ve 6583 say11 2015 Y1lı Merkezi Yönetim Bütçe Kanununa bağlı (A) ișaretli cetvellerine dâhil başlangıç ödeneklerinin hangi oranlarında ödenek kullanım yetkisinin verildiğini sıralamaktadır.

26 Mayıs 2016 Anayasa Mahkemesinin 2015 Merkezi Yönetim Bütçe Kanunu'nun Bazı Hükümlerini Iptal Etmesi

Anayasa Mahkemesi'nin 2015/7 E.2016/47 K. sayılı ve 26 Mayıs 2016 tarihli karar1 2015 Merkezi Yönetim Bütçe Kanunun bazı hükümleri iptal edildi. Karar Resmi Gazetede 22 Eylül 2016'da yayımland1.

İptal edilen hükümler arasında en önemlisi TBMM'nin onayı alınması gereken bir konuda Yürütme organına yetki veren düzenleme oldu. Anayasa Mahkemesinin kararı ile Maliye Bakanı'na, Merkezi yönetim kapsamındaki idarelerin (Genel ve özel bütçeli idarelerin) bütçelerindeki ödeneklerini, 5018 sayılı Kamu Mali Yönetimi ve Kontrol Kanunun 21 inci maddesinde yer alan sınırlamalara tabi olmaksızın diğer kuruluşlara ve Maliye Bakanlığ 1 "Yedek Ödeneğine" aktarma yetkisi veren hüküm iptal edildi.

İptal edilen bir diğer önemli hüküm ise, merkezi yönetim kapsamındaki idarelerce hizmet alımı suretiyle edinilmesi ekonomik olmayan taşıtlar, Merkezi Yönetim Bütçe Kanununa bağlı $(\mathrm{T})$ işaretli cetvelde gösterilmesine gerek bulunmaksızın satın alınabileceğine ilişkin hükümdü (Anayasa Mahkemesi Karar1, 2015).

Başvuru sahibi olan CHP'nin konuya ilişkin görüşü şu şekilde oldu:

“Anayasa Mahkemesi, CHP’nin 2015 Merkezi Yönetim Bütçe Kanunu ile ilgili iptal başvurusunu 2015 yılı içerisinde ele alıp sonuçlandırmadı. Davayı 26 Mayıs 2016 tarihinde ele alarak CHP'nin yaptığı iptal talebini neredeyse tamamiyle haklı buldu. Hem geç alındığı hem de Resmi Gazete'de geç yayımlandığı için iptal kararı 2015 yılı bütçe uygulamasıyla ilgili olarak fiili bir sonuç doğurmayacak.

İptal edilen bütün hükümler, aynı cümlelerle 2016 y1lı bütçesinde de yer alıyor. Anayasa Mahkemesi iptal kararını 2015 yılı içerisinde ya da 2016 yılının ilk 
aylarında açıklasaydı, iptal edilen bu hükümler 2016 bütçesinde yer almayabilirdi. (2016 bütçesi 1 Nisan 2016 tarihinde yürürlüğe girdi)

Anayasa Mahkemesi'nin bir başka anlaşılmaz tutumu ise 26 Mayıs 2016 tarihinde aldığı bir iptal kararının gerekçesini yaklaşık dört ay sonra açıklamasıdır.

Maliye Bakanı, mesela Milli Eğitim Bakanlığına TBMM'nin verdiği ödeneğin 18 milyar lirasını, Emniyet Genel Müdürlüğünün ödeneklerin 3,3 milyarını, Diyanet İşleri Başkanlığının ödeneklerinin 1,4 milyar lirasını, Türkiye Kamu Hastaneleri Kurumu'nun ödeneklerinin 2,5 milyar lirasını alıp başka kuruluşlara aktardı. Bu yetkiyle örneğin, Cumhurbaşkanına TBMM'nin verdiği 434 milyon liralık bütçe, Maliye Bakanı tarafından 710 milyar liraya çıkarıldı. Maliye Bakanlığının ödeneği 18,9 milyar lira artırıldı. Milli Savunma Bakanlığının bütçesi11 milyar lira yükseltildi” (CHP, 2016).

\section{A ğustos 2016 Vergi Affi}

3 Ağustos 2016 tarihinde kabul edilen 6736 sayılı Bazı Alacakların Yeniden Yapılandırılmasına İlişkin Kanun 19 Ağustos 2016 tarihinde Resmi Gazetede yayımland1.

Gelir İdaresi Başkanlığının "Vergide Büyük Yapılandırma Fırsatı Başladı" şeklinde duyurduğu düzenlemelerle "30.06.2016 tarihi itibariyle gecikmiş vergi borçlarında Yurt İçi ÜFE oranında güncelleme; Motorlu Taşıtlar Vergisi ve Trafik Para Cezalarında önemli indirim; peşin ödemelerde Yurt İçi ÜFE oranında hesaplanan tutardan ayrıca $\% 50$ indirim; vergi aslına bağlı olmayan usulsüzlük ve özel usulsüzlük cezalarının \%50'sinin silinmesi; Varlık Barış1; Vergi ihtilaflarının sulh yoluyla sonlandırılmasında \%80'e varan indirim; işletme kayıtlarının cezasız ve faizsiz olarak gerçek duruma uygun hale getirilmesi; eczanelerde cezası faizsiz stok düzeltme; matrah ve vergi artırımında vergi incelemesinden muafiyet; inceleme ve tarhiyat safhasındaki borçlar için yapılandırma; beyan edilmemiş gelirler ve kazançlar için pişmanlıkla cezasız ve faizsiz beyan; yapılandırılan borçları anlaşmalı bankaların banka kartı ve kredi kartı ile ödeme; 6552 sayılı Kanun kapsamında devam eden borçların yeniden yapılandırılması; vadesi 31.12.2011 tarihinden önce olan 50 TL ve altındaki borçların silinmesi, gibi çok önemli imkanlar getirilmiştir" (GİB, 2016).

\section{Kasım 2016 Ödenek Aktarma Limitlerinin Arttırılması}

16 Kasım 2016'de kabul edilen Kamu Mali Yönetimi ve Kontrol Kanunu ile Bazı Kanunlarda Değişiklik Yapılması Hakkında Kanun, 24 Kasım 2016'da Resmi Gazetede yayımland. 
Buna göre, 5018 sayılı Kamu Malî Yönetimi ve Kontrol Kanununun Ödenek Aktarmaları başlıklı 21'inci maddesi aşağıdaki şekilde değiştirildi:

"Madde 21- Merkezî yönetim kapsamındaki kamu idarelerinin bütçeleri arasındaki ödenek aktarmaları kanunla yapılır. Ancak, harcamalarda tasarrufu sağlamak, dengeli ve etkili bir bütçe politikasını gerçekleştirmek üzere genel bütçe ödeneklerinin yüzde onunu geçmemek kaydıyla, merkezî yönetim kapsamındaki kamu idarelerinin bütçeleri arasındaki ödenek aktarmalarına ilişkin yetki ve işlemler ile usul ve esaslar merkezî yönetim bütçe kanununda belirlenir.

Merkezî yönetim kapsamındaki kamu idareleri, aktarma yapılacak tertipteki ödeneğin yüzde yirmisine kadar kendi bütçeleri içinde ödenek aktarması yapabilirler. Ancak, ihtiyaç halinde yüzde yirmiyi aşan ödenek aktarma işlemlerini kurum bütçesinin başlangıç ödenekleri toplamının yüzde yirmisini geçmemek üzere yapmaya Maliye Bakanlığı, yılı yatıım programına ek yatırım cetvellerinde yer alan projelerde değişiklik yapılması halinde değişikliğin gerektirdiği tertipler arası ödenek aktarması işlemlerinin tamamını yapmaya ise ilgili idareler yetkilidir.

Kamu idarelerinin bütçeleri içinde; personel giderleri tertiplerinden, aktarma yapılmış tertiplerden ve yedek ödenekten aktarma yapılmış tertiplerden diğer tertiplere ödenek aktarılamaz. Ancak, yılı yatırım programına ek yatırım cetvellerinde yer alan projelerde değişiklik yapılması halinde, aktarma yapılan tertiplerden diğer tertiplere ödenek aktarılabilir."

Madde 21'in değişiklikten önceki hali şu şekildedir:

"Merkezi yönetim kapsamındaki kamu idarelerinin bütçeleri arasındaki ödenek aktarmaları kanunla yapılır.

Ancak, merkezi yönetim kapsamındaki kamu idareleri, aktarma yapılacak tertipteki ödeneğin y1lı bütçe kanununda farklı bir oran belirlenmedikçe yüzde beşine kadar bütçeleri içinde ödenek aktarması yapabilirler. Bu şekilde yapılan aktarmalar, yedi gün içinde Maliye Bakanlığına bildirilir.

Personel giderleri tertiplerinden, aktarma yapılmış tertiplerden ve yedek ödenekten aktarma yapılmış tertiplerden, diğer tertiplere aktarma yapılamaz."

Yapılan değişikliklerle "Bu yasaya göre bütçe ödeneklerinden \%20'ye kadar olan sapma artık yasal. İlgili Kamu İdareleri, aktarmak istedikleri tertipteki ödeneğin \%20'sine kadarını kimseye sormadan; kendilerine verilmiş bütçe ödenekleri toplamının \%20'sine kadarını ise Maliye Bakanlığı'nın izniyle, başka tertiplere aktarabilecek. Küçük bir hesap yapalım: 2017 y1lı bütçesi 717 milyar 825 milyon lira, \%20'si 143 milyar 565 milyon lira ediyor. Buna göre 143 milyar lira büyüklüğünde bir tutar, Meclisin öngörmediği/izin vermediği yerlerde kullanabilir ve kimse bir şey söyleyemez, yasaya uygun" (Sev, 2016b). 
19 Aralık 2016 Istanbul Büyükşsehir Belediyesinin 2017'de Sukuk İhracı Yapacağı Haberi

Hazine'nin ilk kez 2010'da gerçekleştirdiği sukuk ihracının ardından, yerel yönetimlerin de sukuk ihraç edeceği haberi basına yansıdı. Sabah Gazetesi’nden Dilek Güngör'ün 19 Aralık 2016 tarihli haberine göre "2017'nin ilk çeyreğinde İstanbul Büyükşehir Belediyesi'nin sukuk, Antalya Büyükşehir Belediyesi'nin de tahvil ihracına çıkaca(k)" (Güngör, 2016).

Sayıştay emekli denetmeni Kadir Sev'in yorumuna göre: "Kentsel dönüşüm kuralları uygulanarak yapılan bütün yapılar, menkul değere dönüştürülecek ve borsaya sürülecek. Vergi stopaj oranlarını da düşürecekleri için bu tahviller, daha yüksek fiyatlarla işlem görebilecek. Belediyelere güvensizlik sorununu, Hazine ya da iller Bankası garantisi vererek çözecekleri anlaşılıyor. Belediyelerin ödeyemedikleri borçlarını Hazine ya da İlbank ödeyecek ve bütçe paylarından keserek alacaklarını tahsil edecekler” (Sev, 2016 a).

\section{Aralık 2016 Kamu Haznedarlığı Genel Tebliği ile Döviz ve Faiz Müdahalesi}

29912 sayılı Resmi Gazetede 8 Aralık 2016'da yayımlanan Kamu Haznedarlı̆̆ Genel Tebliği ile kamu kurum ve kuruluşlara "kendi bütçeleri ya da tasarrufları altında bulunan her türlü mali kaynaklarını TCMB veya muhabiri olan bankada açılacak TL cinsi vadesiz hesaplarda" tutma yükümlülüğü getirildi.

Tebliğin 6. Maddesiyle; "Kurumların mevduat ve katılma hesabı olarak değerlendirmeyi öngördükleri mali kaynakları için uygulanacak vadeli mevduat faiz oranı ve katılma hesabı beklenen/tahmini getiri oran1, Ek 1'de yer alan ve ilgili vadelere karşıllk gelen oranlardan daha yüksek olamaz" hükmü ile faizlere tavan limiti getirildi.

Ayrıca Bankaların, yüksek faiz isteyen kamu yöneticilerini Hazine Müsteşarlığına şikâyet etmeleri isteniyor. Yüksek nema elde edildiği saptanırsa bütçeye gelir yazılması öngörülüyor (Sev, 2016c).

\section{Ağustos 2016 Zorunlu Bireysel Emeklilik Sistemi}

10 Ağustos 2016 tarihinde kabul edilen 6740 say1lı Bireysel Emeklilik Tasarruf ve Yatııım Sistemi Kanununda Değişiklik Yapılmasına Dair Kanun ile 45 yaşını doldurmamış olan tüm kamu ve özel kesim çalışanlarının otomatik olarak bir emeklilik planına dahil edilmesi yasalaştı. 1 Ocak 2017'de itibaren kademeli olarak tahminen 6 milyon çalışan otomatik BES'e girecek. 


\section{Aralık 2016 Türkiye Varlık Fonu Yönetimi}

19 Ağustos 2016'da kabul edilen 6741 sayılı ve "Türkiye Varlık Fonu Yönetimi Anonim Şirketinin Kurulması ile Bazı Kanunlarda Değişiklik Yapılmasına Dair Kanun" isimli kanun 26 Ağustos 2016 tarihinde Resmi Gazetede yayınland1.

Kanunun amacı şu şekilde tanımlanmakta: "Bu Kanunun amacı sermaye piyasalarında araç çeşitliliği ve derinliğine katkı sağlamak, yurtiçinde kamuya ait olan varlıkları ekonomiye kazandırmak, dış kaynak temin etmek, stratejik, büyük ölçekli yatırımlara iştirak etmek için Türkiye Varlık Fonu ve bu fona bağl1 alt fonları kurmak ve yönetmek üzere Türkiye Varlık Fonu Yönetimi Anonim Şirketinin (Şirket) kurulması, yönetimi ve faaliyetlerine ilişkin esasları düzenlemektir".

İlgili şirket, yapısı ve işleyişine ilişkin usul ve esaslar Bakanlar Kurulu tarafindan belirlenmek üzere, Başbakanlığa bağll, profesyonel yönetim ilkelerine göre yönetilen, özel hukuk hükümlerine tabi olarak ve gerek görülmesi halinde alt fonlara sahip olabilecek şekilde kuruldu.

Yasa ile sadece şirket kurulmamakta ayrıca şirketi kamusal sorumluluklardan bağışık kılacak müthiş bir istisna ve muafiyet zırhı örüldü. İlgili 8'inci madde şu şekilde:

“1) Bu Kanuna göre kurulan Şirket ve Türkiye Varlık Fonu ile Şirket tarafindan kurulacak şirketler ve alt fonlar gelir ve kurumlar vergisinden muaftır. $\mathrm{Bu}$ muafiyet, bunların kazanç ve iratları üzerinden 31/12/1960 tarihli ve 193 sayılı Gelir Vergisi Kanunu ile 13/6/2006 tarihli ve 5520 say1l Kurumlar Vergisi Kanunu uyarınca yapılacak vergi kesintilerini de kapsar.

(2) Şirket ve Türkiye Varlık Fonu ile Şirket tarafindan kurulacak şirketler ve alt fonlar, elektrik ve havagazı tüketim vergisi ve yangın sigortası vergisi hariç olmak üzere 26/5/1981 tarihli ve 2464 sayıl1 Belediye Gelirleri Kanunu gereğince alınan vergi, harç, katılma payı ile tasdik ücretlerinden, sahip olduğu taşınmazlar dolayısıyla emlak vergisinden, satın alınan ve satılan taşınmazlar ile ilgili olarak tapu ve kadastro döner sermaye bedellerinden ve her türlü dava ve icra işlemlerinde teminat yatırma mükellefiyetlerinden muaftır.

(3) Şirket ve Türkiye Varlık Fonu ile Şirket tarafindan kurulacak şirketler ve alt fonların kuruluş ve tescil işlemleri ile esas sözleşmesinin tescil ve ilan işlemleri de dâhil olmak üzere faaliyetleri kapsamında gerçekleştirdikleri işlemlerle ilgili düzenlenen tüm kâğtlar damga vergisinden, tüm iş ve işlemleri her türlü harçtan, her ne nam adı altında olursa olsun nakden veya hesaben banka ve sigorta muameleleri vergisi mükelleflerine ödedikleri tutarlar ile her ne nam adı altında olursa olsun nakden veya hesaben lehe aldıkları paralar banka ve sigorta muameleleri vergisinden, her türlü kredi kullanım işlemleri kaynak kullanımını destekleme fonundan istisnadır. 
(4) Şirket ve Türkiye Varlık Fonu ile Şirket tarafından kurulacak şirketler ve alt fonlar, kamu iktisadi teşebbüsleri de dâhil, sermayesinin yarısından fazlası kamuya ait olan veya özel kanunla kurulan kamu kurum, kuruluş ve ortaklıklarına uygulanan mevzuat, uygulama ve kısıtlamalara tabi değildir.

(5) 3/12/2010 tarihli ve 6085 sayılı Sayıştay Kanunu, 6362 sayılı Kanun ile bu Kanun uyarınca yürürlüğe konulan ikincil mevzuat, 8/6/1984 tarihli ve 233 sayılı Kamu İktisadi Teşebbüsleri Hakkında Kanun Hükmünde Kararname, 22/1/1990 tarihli ve 399 say1lı Kamu İktisadi Teşebbüsleri Personel Rejiminin Düzenlenmesi ve 233 Sayılı Kanun Hükmünde Kararnamenin Bazı Maddelerinin Yürürlükten Kaldırılmasına Dair Kanun Hükmünde Kararname, 14/7/1965 tarihli ve 657 say1l Devlet Memurları Kanunu, 4/7/2001 tarihli ve 631 sayılı Memurlar ve Diğer Kamu Görevlilerinin Mali ve Sosyal Haklarında Düzenlemeler ile Bazı Kanun ve Kanun Hükmünde Kararnamelerde Değișiklik Yapılması Hakkında Kanun Hükmünde Kararname, 13/12/1983 tarihli ve 190 sayılı Genel Kadro ve Usulü Hakkında Kanun Hükmünde Kararname, 18/5/1994 tarihli ve 527 sayılı Memurlar ve Diğer Kamu Görevlileri ile İlgili Bazı Kanun ve Kanun Hükmünde Kararnamelerde Değişiklik Yapılmasına Dair Kanun Hükmünde Kararname, 10/2/1954 tarihli ve 6245 sayılı Harcirah Kanunu, 2/4/1987 tarihli ve 3346 sayılı Kamu İktisadi Teşebbüsleri ile Fonların Türkiye Büyük Millet Meclisince Denetlenmesinin Düzenlenmesi Hakkında Kanun, 4/1/2002 tarihli ve 4734 sayıl Kamu İhale Kanunu, 5/1/2002 tarihli ve 4735 sayılı Kamu İhale Sözleşmeleri Kanunu, 8/9/1983 tarihli ve 2886 sayılı Devlet İhale Kanunu, 5/1/1961 tarihli ve 237 sayılı Taşıt Kanunu, 9/11/1983 tarihli ve 2946 sayılı Kamu Konutlar1 Kanunu, 2/1/1961 tarihli ve 195 sayılı Basın-İlân Kurumu Teşkiline Dair Kanun, 7/12/1994 tarihli ve 4054 sayılı Rekabetin Korunması Hakkında Kanun, 24/11/1994 tarihli ve 4046 sayılı Özelleştirme Uygulamaları Hakkında Kanun ile bunların ek ve değişikliklerine ilişkin hükümler Türkiye Varlık Fonu ve Şirket ile alt fonlar ve Şirket tarafindan kurulan diğer şirketler hakkında uygulanmaz. Kamu kurum ve kuruluşlarına personel alınmasına dair ilgili mevzuat hükümleri Şirket tarafindan istihdam edilecek personel hakkında uygulanmaz.

(6) Şirket tarafindan kurulacak varlık kiralama şirketleri 28/3/2002 tarihli ve 4749 sayılı Kamu Finansmanı ve Borç Yönetiminin Düzenlenmesi Hakkında Kanunun 7/A maddesi çerçevesinde kurulan varlık kiralama şirketlerine tanınan tüm hak, istisna, indirim ve muafiyetlerden yararlanır. $\mathrm{Bu}$ madde uyarınca kurulan varlık kiralama şirketleri, ihraç etmiş oldukları menkul kıymetlere ilişkin, ihraççıların tabi olduğu Borsa İstanbul Anonim Şirketine ödenmesi gereken kayıt ücreti ve kotasyon ücretinden muaftır."

Şirketin 50.000.000 (elli milyon) Türk lirası olan kuruluş sermayesi Özelleştirme Fonundan karşılandı. 


\section{Kasım 2016 TVF'nin İşleyişine İlişkin Bakanlar Kurulu Kararı}

Bakanlar Kurulu'nca 17/10/2016 tarihinde kararlaştırılan “Türkiye Varlık Fonu Yönetimi Anonim Şirketinin Yapısına ve İşleyişine İlişkin Usul ve Esaslar Hakkında Karar" 9 Kasım 2016 tarihinde Resmi Gazetede yayımlandı.

20'nci maddesinde TVF'nin kaynakları şu şekilde tanımlanmakta:

“a) Özelleştirme Yüksek Kurulu tarafindan; özelleştirme kapsam ve programında bulunan ve TVF'ye devrine karar verilen kuruluş ve varlıklar ile Özelleştirme Fonundan TVF'ye aktarılmasına karar verilen nakit fazlasından,

b) Kamu kurum ve kuruluşlarının tasarrufu altında bulunan ihtiyaç fazlası gelir, kaynak ve varlıklardan, Bakanlar Kurulu tarafindan TVF'ye aktarılmasına veya Şirket tarafından yönetilmesine karar verilenlerden,

c) TVF tarafından yurt içi ve yurt dışı sermaye ve para piyasalarından ilgili mevzuat kapsamında yer alan izin ve onaylar aranmaksızın sağlanan finansman ve kaynaklardan,

ç) Para ve sermaye piyasaları dışında diğer yönetimlerle sağlanan finansman ve kaynaklardan, oluşur."

Türkiye Varlık Fonuna finansman sağlanmasını tanımlayan 24'üncü maddesi şu şekilde: "TVF, her türlü yurt içi ve yurt dışı sermaye ve para piyasalarından, ilgili mevzuat kapsamında yer alan izin ve onaylar aranmaksızın finansman ve kaynak sağlayabilir.”

\section{Aralık 2016 Tamamlayıcı Ödenek}

16 Aralık 2016 tarihinde kabul edilen 2015 Y11 Merkezi Yönetim Kesin Hesap Kanunu 24 Aralık 2016'da Resmi Gazetede yayımlandı. Kanunun 4'üncü maddesindeki hükme göre “(...) kamu idarelerinin 2015 yılı ödenek üstü giderlerini karşılamak üzere, 5018 sayılı Kanuna ekli; a) (I) sayılı cetvelde yer alan genel bütçe kapsamındaki kamu idareleri için toplam 31.207.551.183,33 Türk lirası (...) tamamlayıcı ödenek kabul edilmiştir”.

Buna göre genel bütçe kapsamındaki kamu idarelerine verilen 464.163.399.000 TL ödeneklerin üstünde meclise gitmenden yapılan $\% 6,72$ değerindeki harcamaların tamamlayıcı ödenek aktarımı ile yasalaştırılması sağlandı.

“Tamamlayıcı ödenek uygulaması Sayıştay'ın da müsamahası ile 1998'de binde 4'ten 2015'te \%7'i geçen bir orana ulaşarak bir anlamda kurumsallık kazanmış gibi gözüküyor" (Dedeoğlu, 2016)

"Sapma gerçeği bununla kalmıyor; 5018 sayılı Yasayla yasaklanmış olmasına karşın, gözde kuruluşların ödenek üstü harcamalarına göz yumuluyor. Diyanet İşleri Başkanlığı bu konuda en şanslı kuruluşlardan biri; 2015 yılında 3 milyar 
558 milyon lira ödeneği vardı, 6 milyar 37 milyon lira harcadı. Yetkisiz olarak 2 milyar 500 milyon lirayı neden harcadığını kimse sormadı. Geçen hafta Diyanet İşleri Başkanlığının bütçe ve kesin hesabı görüşülürken AKP milletvekillerinin oylarıyla tamamlayıcı ödenek verilip aklandı" (Sev, 2016b).

\section{Ocak 2017 TJK'nin ve Milli Piyango İdaresinin Varlik Fonuna Devredilmesi}

2 Ocak 2017 tarihli Bakanlar Kurulunun kabul ettiği 680 sayılı kararname 6 Ocak 2017'de Resmi Gazetede yayımlandı. KHK'nın 77. Maddesi ile Türkiye Jokey Kulübü'nün yurt içi ve yurt dışında müşterek bahis kabul etme hak ve yetkileri de Türkiye Varlı Fonu'na devredildi. Madde şu şekilde: "10/7/1953 tarihli ve 6132 sayılı At Yarışları Hakkında Kanuna aşağıdaki ek madde eklenmiştir.

"Ek Madde 2- Yurt içinde at yarışları düzenleme, yurt içinde ve yurt dışında düzenlenen at yarışları üzerine yurt içinden ve yurt dışından müşterek bahis kabul etme hak ve yetkilerine ilişkin lisanslar, topluca 1/1/2018tarihinden itibaren 49 yıl süreyle 19/8/2016 tarihli ve 6741 sayılı Türkiye Varlık Fonu Yönetimi Anonim Şirketinin Kurulması ile Bazı Kanunlarda Değişiklik Yapılmasına Dair Kanun hükümleri uyarınca kurulan Fona verilmiştir.

Gıda, Tarım ve Hayvancılık Bakanlığına at yarışları düzenleme amacına yönelik olarak tahsis edilmiş veya fiilen bu amaçla kullanılan taşınmazlar ile üzerlerindeki yapı ve tesisler, 49 y1l süre boyunca lisans sahibi Fonun kullanımına verilir.

Gıda, Tarım ve Hayvancılık Bakanlı̆̆ı, lisans süresince yurt içinde at yarışları düzenleyemez, düzenletemez, yurt içinde ve yurt dışında düzenlenen at yarışları üzerine yurt içinden ve yurt dişından müşterek bahis kabul edemez.

Lisans konusu faaliyetlerin ilgili mevzuat hükümlerine uygun olarak yürütülmesini izlemeye ve denetlemeye Gıda, Tarım ve Hayvancılık Bakanlığı yetkilidir."

Aynı KHK ile şans oyunlarına dair lisans düzenleme hakkı da Türkiye 49 yıllığına Varlık Fonu'na devredildi.

KHK'nın 82’nci maddesi şu şekilde: “4/4/1988 tarihli ve 320 sayılı Milli Piyango İdaresi Genel Müdürlüğü Kuruluş ve Görevleri Hakkında Kanun Hükmünde Kararnamenin ek 2 nci maddesi aşağıdaki şekilde değiştirilmiştir.

Ek Madde 2- Karşılığı nakit olmak üzere oynatılan Piyango, Hemen-Kazan, Sayısal Loto, Şans Topu, On Numara ve Süper Loto oyunları ile ilgili mevzuat çerçevesinde izin verilebilecek olan benzer şans oyunlarına ilişkin lisans, bu maddenin yürürlüğe girdiği tarihten itibaren 49 yıl süreyle 19/8/2016 tarihli ve 6741 sayılı Türkiye Varlık Fonu Yönetimi Anonim Şirketinin Kurulması ile Bazı Kanunlarda Değişiklik Yapılmasına Dair Kanun hükümleri uyarınca 
kurulan Türkiye Varlık Fonuna verilmiştir. Lisansın Türkiye Varlık Fonu tarafindan üçüncü kişilere devredilmesinden sonra, İdare lisansa konu şans oyunlarını düzenleyemez ve bu oyunlar için ayrı bir lisans veremez. Lisans konusu faaliyetlerin ilgili mevzuat hükümlerine uygun olarak yürütülmesini izlemeye ve denetlemeye İdare yetkilidir."

\section{0 Şubat 2017 İzmir Limanın Varlık Fonuna Devredilmesi}

2007 yılından beri özelleştirilme kapsamında olan İzmir Alsancak Limanı, Özelleştirme İdaresi Başkanlığı tarafından Varlık Fonu'na devredildi (T24, 2017).

\section{Ocak 2017 Vergi Affinin Genişletilmesi}

18 Ocak 2017'de kabul edilen 6770 sayıll, Türkiye Cumhuriyeti Emekli Sandığı Kanunu ile Bazı Kanun ve Kanun Hükmünde Kararnamelerde Değişiklik Yapılmasına Dair Kanun, 27 Ocak 2017 tarihli Resmi Gazetede yayımland.

“Anılan kanunun 26'nc1 maddesiyle 6736 say11 Bazı Alacakların Yeniden Yapılandırılmasına İlişkin Kanun'a geçici 2'nci madde eklenmiş olup, anılan madde hükmü ile yapılandırılan borçlara ve ödeme sürelerine ilişkin bazı düzenlemeler yapılarak, ilave imkanlar getirilmiştir. Anılan madde hükmü ile getirilen düzenlemeleri açıklayan ve uygulama usul ve esaslarını belirleyen 5 Seri No.lu Bazı Alacakların Yeniden Yapılandırılmasına İlişkin 6736 sayılı Kanun Genel Tebliği de 29 Ocak 2017 tarihli Resmi Gazetede yayımlanmıştır" (Akarca ve Şafak, 2017).

\section{5 Şubat 2017 TVF'na Aktarllan Kuruluş, Kaynak ve Varlıklar}

24 Ocak 2017 tarihli Türkiye Varlık Fonuna Aktarılan Kuruluş, Kaynak ve Varlıklara ilişkin Bakanlar Kurulu Kararı, 5 Şubat 2017 tarihinde Resmi Gazetede yayımlandı. Buna göre şu kuruluşların TVF'ya aktarımı gerçekleşti: "Türkiye Cumhuriyeti Ziraat Bankası Anonim Şirketi, Boru Hatları ile Petrol Taşıma Anonim Şirketi, Türkiye Petrolleri Anonim Ortaklığı, Posta ve Telgraf Teşkilatı Anonim Şirketi, Borsa İstanbul Anonim Şirketi, Türksat Uydu Haberleşme Kablo TV ve İşletme Anonim Şirketinin sermayelerinde bulunan Hazineye ait hisselerin tamamı, Türk Telekomünikasyon Anonim Şirketinin \%6,68 oranındaki Hazineye ait hisse ile Eti Maden İşletmeleri Genel Müdürlüğü ve Çay İşletmeleri Genel Müdürlüğü’”.

31 Ocak 2017 tarihli Türkiye Varlık Fonuna Kaynak Aktarılmasına İlişkin Bakanlar kurulu kararı yine 5 Şubat 2017 tarihinde Resmi Gazetede yayımlanan bir diğer karar oldu. Bura göre "Savunma Sanayii Destekleme Fonuna ait veya 
bu Fonun tasarrufunda bulunan 3 milyar Türk Lirası tutarındaki kaynağın, en geç aktarım tarihini izleyen 3 at içerisinde geri ödenmek kaydıyla Türkiye Varlık Fonuna aktarılması kararlaştırılmıştır."

Çiğdem Toker'in konuya ilişkin tespitleri şu şekilde: “TVF'ye yine OHAL KHK'siyle Savunma Sanayi Destekleme Fonu'ndan (SSDF) 3 milyar TL aktarılmasına karar verildi. Bütçeden geçen sene SSDF'ye verilen pay 5 milyar TL'ye yakın. Yani SSDF'nin 6-7 ay boyunca birikimli olarak kendisine aktarılan bir tutarı, tek kalemde TVF'ye verdiği bir operasyondan söz ediyoruz. Peki, biz bu 3 milyar TL'nin nerelere ve nasıl harcandığını biliyor muyuz? Cevap: Hayır" (Toker, 2017).

TVF'na devredilen bankaların görev zararlarına ilişkin de yine benzer bir eleştiriyi şu şekilde dile getiriyor: "Yıllar sonra yeniden konuşmaya başladığımız görev zararları, bugün için düşük tutarlarda görünse de TVF'nin Sayıştay denetimi dışında tutulması, çok eskide kaldığı sanılan bu riski yeniden gündeme taşıyabilir. Biz şu anda Maliye Muhasebat Genel Müdürlüğü verileri altında, iki kamu bankasına aktarılan görev zararı tutarlarını izleyebiliyoruz. Peki, bundan sonra Meclis adına denetim yolu kapatılan bir TVF yapısının, görev zararının gerçek boyutlarını örtmeyeceğini kim söyleyebilir?" (Toker, 2017).

Oğuz Oyan'ın tespitleri ise şu şekildedir: "Bütçesi ve ödemeler dengesi açık veren, uluslararası yatırım pozisyonu açık veren, Hazine üstlenimleri vs. üzerinden bütçe açıklarını çok aşan kamu açıkları veren bir ekonomide 'ulusal varlık fonu' veya 'ulusal yatırım fonu' gibi bir fon oluşturmanın maddi koşulları oluşmamış demektir.

Demek ki, karşı karşıya olduğumuz fon yapılanması çok farklı bir düzenektir. Bunu çok farklı ve görülmemiş bir uygulama yapan bir diğer işaret de, öz kaynaklarıyla değil de mevduat ve dış borçlanma üzerinden kaynak oluşturarak faaliyet gösteren bankaların da bu fon kapsamına alınmış olmasıdır. Bu, bu tür fonların amaçlarına uygun değildir. Kaldı ki, böylesine kozmopolit kuruluş ve varlıklar bütününün yönetilebilir bir yapı olması da mümkün değildir." "Bu, bir yandan bütçe dışı kamu açıklarının artık gizlenemez boyutlarının ve risklerinin dağıtılması operasyonudur; diğer yandan ise, sıra bekleyen büyük projelerin finansman sorunlarının (gene gelecek nesillere yük aktarmak kurgusu üzerinden) bugün için 'halledilmesi' teşebbüsüdür” (Oyan, 2017).

\section{1 Şubat 2017 Anayasa Değişikliği ile Bütçe Hakkının Partili Cumhurbaşkanı'na Devredilmesi}

21 Ocak 2017'de kabul edilen 6771 Sayılı "Türkiye Cumhuriyeti Anayasası'nda Değişiklik Yapılmasına Dair Kanun” 11 Şubat 2017'de Cumhurbaşkanı 
tarafından onaylandı ve halkoyuna sunulmak üzere yayımlanması için Başbakanlığa gönderildi.

Kamu maliyesini ilgilendiren Anayasa değişikliği, Anayasanın 161'inci maddesinde bütçe kanun teklifinin artık Cumhurbaşkanı tarafindan hazırlanmasına ilişkin olarak gerçekleşti.

"Cumhurbaşkanı bütçe kanun teklifini, malî yılbaşından en az yetmişbeş gün önce, Türkiye Büyük Millet Meclisine sunar. Bütçe teklifi Bütçe Komisyonunda görüşülür. Komisyonun ellibeş gün içinde kabul edeceği metin Genci Kurulda görüşülür ve mali yılbaşına kadar karara bağlanır."

Önemli bir diğer değişiklik ise geçici bütçeye ilişkindir. "Bütçe kanununun süresinde yürürlüğe konulamaması halinde, geçici bütçe kanunu çıkarılır. Geçici bütçe kanununun da çıkarılamaması durumunda, yeni bütçe kanunu kabul edilinceye kadar bir önceki yılın bütçesi yeniden değerleme oranına göre artırılarak uygulanır."

Böylece Türkiye Büyük Millet Meclisine ait olan bütçe hakkının ortadan kalktığı bir durum ortaya çıkmaktadır (BB, 2017). Anayasa değişikliği ile ortada yasalaşmış bir bütçe kanunu olmaksızın bir bütçe uygulanabilir hale getirilmektedir.

Halihazırda geçerli olan 5018 sayılı yasanın 19'uncu maddesinde ise tanımlanan geçici bütçe şu şekildedir: "Zorunlu nedenlerle merkezî yönetim bütçe kanununun süresinde yürürlüğe konulamaması halinde, geçici bütçe kanunu çıkarılır. Geçici bütçe ödenekleri, bir önceki yıl bütçe başlangıç ödeneklerinin belirli bir oranı esas alınarak belirlenir. Geçici bütçe uygulaması altı ayı geçemez. Cari yıl bütçesinin yürürlüğe girmesiyle geçici bütçe uygulaması sona erer ve o tarihe kadar yapılan harcamalar ve girişilen yüklenmeler ile tahsil olunan gelirler cari yıl bütçesine dahil edilir."

\section{Mart 2017 Türkiye-Rusya Yatırım Fonunun Kurulması}

Türkiye Varlık Fonunun ilk uluslararası girișimlerinden biri olarak, Rusya Doğrudan Yatırım Fonu ile birlikte her iki ülkenin 500'er milyon dolar fon katılımıyla toplam 1 milyar dolar büyüklügünde Türkiye-Rusya Yatırım Fonu kurulması için mutabakat anlaşması imzalandı (AA, 2017).

\section{Ek: OVP ve OVMP'nin Fiili Takvimi}

5018'e göre Orta Vadeli Programın hazırlanma ve yayımlanma tarihleri 16'ncı maddede şu şekilde düzenlenmiştir: "Maliye Bakanlığı, merkezî yönetim bütçe kanunu tasarısının hazırlanmasından ve bu amaçla ilgili kamu idareleri arasında koordinasyonun sağlanmasından sorumludur. Merkezî yönetim bütçesinin hazırlanma süreci, Bakanlar Kurulunun en geç Eylül ayının ilk haftası sonuna 
kadar toplanarak kalkınma planları, stratejik planlar ve genel ekonomik koşulların gerekleri doğrultusunda makro politikaları, ilkeleri, hedef ve gösterge niteliğindeki temel ekonomik büyüklükleri de kapsayacak şekilde Devlet Planlama Teşkilatı Müsteşarlı̆̆ınca hazırlanan orta vadeli programı kabul etmesiyle başlar. Orta vadeli program, aynı süre içinde Resmî Gazetede yayımlanır."

\begin{tabular}{|c|c|c|c|}
\hline $\begin{array}{c}\text { Orta Vadeli } \\
\text { Program }\end{array}$ & $\begin{array}{c}\text { Kalkınma } \\
\text { Bakanlı̆̆ının yazısı* }\end{array}$ & $\begin{array}{c}\text { Bakanlar } \\
\text { Kurulu Kararı }\end{array}$ & Resmi Gazete \\
\hline $2017-2019$ & $5 / 9 / 2016$ & $7 / 9 / 2016$ & 6 Ekim 2016 (29849) \\
\hline $2016-2018$ & $23 / 12 / 2015$ & $29 / 12 / 2015$ & 11 Ocak 2016(29590) \\
\hline $2016-2018$ & $4 / 9 / 2015$ & $4 / 9 / 2015$ & 11 Ekim 2015(29499) \\
\hline $2015-2017$ & $5 / 9 / 2014$ & $5 / 9 / 2014$ & 8 Ekim 2014 (29139) \\
\hline $2014-2016$ & $5 / 9 / 2013$ & $9 / 9 / 2013$ & 8 Ekim 2013(28789) \\
\hline $2013-2015$ & $6 / 9 / 2012$ & $10 / 9 / 2012$ & 9 Ekim 2012 (28436) \\
\hline $2012-2014$ & $7 / 10 / 2011$ & $7 / 10 / 2011$ & 13 Ekim 2011 (28083) \\
\hline $2011-2013$ & $8 / 10 / 2010$ & $8 / 10 / 2010$ & 10 Ekim 2010 (27725) \\
\hline $2010-2012$ & $13 / 7 / 2009$ & $14 / 7 / 2009$ & 16 Eylü1 2009 (27351) \\
\hline $2009-2011$ & $24 / 6 / 2008$ & $25 / 6 / 2008$ & 28 Haziran 2008 (26920) \\
\hline $2008-2010$ & $25 / 5 / 2007$ & $28 / 5 / 2007$ & 21 Haziran 2007 (26559) \\
\hline $2007-2009$ & $30 / 5 / 2006$ & $30 / 5 / 2006$ & 13 Haziran 2006 (26197) \\
\hline $2006-2008$ & $23 / 5 / 2005$ & $23 / 5 / 2005$ & 31 Mayıs 2005 (25831) \\
\hline
\end{tabular}

*2010 yılı dahil olmak üzere öncesi, Devlet Planlama Teşkilatı Müsteşarlığı

Kaynak: İlgili tarihlerdeki Resmi Gazeteler

5018'e göre Orta Vadeli Mali Planın hazırlanma ve yayımlanma tarihleri 16'ncı maddede şu şekilde düzenlenmiştir:

"Orta vadeli program ile uyumlu olmak üzere, gelecek üç yıla ilişkin toplam gelir ve gider tahminleri ile birlikte hedef açı ve borçlanma durumu ile kamu idarelerinin ödenek teklif tavanlarını içeren ve Maliye Bakanlığı tarafından hazırlanan orta vadeli malî plan, en geç Eylül ayının onbeşine kadar Yüksek Planlama Kurulu tarafından karara bağlanır ve Resmî Gazetede yayımlanır." 


\begin{tabular}{|c|c|c|c|}
\hline $\begin{array}{c}\text { Orta Vadeli } \\
\text { Mali Plan }\end{array}$ & Maliye Bakanlı̆̆ & $\begin{array}{c}\text { Yüksek Planlama } \\
\text { Kurulu }\end{array}$ & Resmi Gazete \\
\hline $2017-2019$ & $22 / 09 / 2016$ & $23 / 09 / 2016$ & 6 Ekim 2016 (29849) \\
\hline $2016-2018$ & $23 / 12 / 2015$ & $06 / 01 / 2016$ & 11 Ocak 2016 (29590) \\
\hline $2016-2018$ & $14 / 09 / 2015$ & $15 / 09 / 2015$ & 11 Ekim 2015 (29499) \\
\hline $2015-2017$ & $26 / 9 / 2014$ & $2 / 10 / 2014$ & 11 Ekim 2014 (29142) \\
\hline $2014-2016$ & $02 / 10 / 2013$ & $04 / 10 / 2013$ & 8 Ekim 2013 (28789) \\
\hline $2013-2015$ & $4 / 10 / 2012$ & $4 / 10 / 2012$ & 9 Ekim 2012 (28436) \\
\hline $2012-2014$ & $10 / 10 / 2011$ & $11 / 10 / 2011$ & 13 Ekim 2011 (28083) \\
\hline $2011-2013$ & $8 / 10 / 2010$ & $8 / 10 / 2010$ & 10 Ekim 2010 (27725) \\
\hline $2010-2012$ & $14 / 9 / 2009$ & $17 / 9 / 2009$ & 18 Eylül 2009 (27353) \\
\hline $2009-2011$ & $27 / 6 / 2008$ & $1 / 7 / 2008$ & 8 Temmuz 2008 (26930) \\
\hline $2008-2010$ & $13 / 6 / 2007$ & $15 / 6 / 2007$ & 3 Temmuz 2007 (26571) \\
\hline $2007-2009$ & $14 / 6 / 2006$ & $14 / 6 / 2006$ & 15 Temmuz 2006 (26229) \\
\hline $2006-2008$ & $14 / 6 / 2005$ & $14 / 6 / 20065$ & 02 Temmuz 2005 (25863) \\
\hline
\end{tabular}

Kaynak: İlgili tarihlerdeki Resmi Gazeteler

\section{Kaynakça}

Akarca, Akif ve Mehmet Şafak (2017), "6736 sayılı Kanun Kapsamında Yapılandırılan Ödemelerde Süre Uzatımı ve Son Hak”, Dünya Gazetesi, 2 Şubat 2017.

Akkaya, Caner (2011), Mortgage Sistemi, Ülkemizde ve Diğer Ülkelerdeki Uygulamaları (Ankara: Tapu ve Kadastro Genel Müdürlüğü).

Anadolu Ajansı (2017), "Türkiy-Rusya Yatırım Fonu için İmzalar Atılı", http://aa.com.tr/tr/ekonomi/turkiye-rusya-yatirim-fonu-icin-imzalaratildi/768552?amp $=1$

Anayasa Mahkemesi Kararı, 2015/7 E.2016/47 K.

Bağımsız Sosyal Bilimciler (2006), IMF Gözetiminde On Uzun Yıl, 1998-2008: Farklı Hükümetler, Tek Siyaset (İstanbul: Yordam Yayınları). 
Bağımsız Sosyal Bilimciler (2008), 2008 Kavşağında Türkiye: Siyaset, Iktisat ve Toplum (İstanbul: Yordam Kitap).

Barolar Birliği (2017), Anayasa Değişikliği Teklifi'nin Karşılaştırmalı ve Açıklamalı Metni, http://anayasadegisikligi.barobirlik.org.tr/Anayasa_Degisikligi.aspx.

CHP (2016), “CHP Grup Başkanvekili Levent Gök'ün AYM'nin 2015 yılı Merkezi Yönetim Bütçe Kanunun Bazı Maddelerini İptal Etmesiyle İlgili Değerlendirmeleri" https://www.chp.org.tr/Haberler/29/gokun-anayasa-mahkemesinin-2015-yilibutce-kanununuyla-ilgili-iptal-karari-degerlendirmesi-27639.aspx

Dedeoğlu, Emin (2016), Kamu Mali Yönetiminde Neler Oluyor? Varlık Fonu ve Tamamlayıcı Ödenek, Değerlendirme Notu, http://www.tepav.org.tr/upload/files/1473014698-

4.Kamu_Mali_Yonetiminde_Neler_Oluyor_Varlik_Fonu_Ve_Tamamlayici_Oden ek.pdf

Gelir İdaresi Başkanlığı (2016), "Vergide Büyük Yapılandırma Fırsatı Başladı", http://www.gib.gov.tr/vergide-buyuk-yapilandirma-firsati-basladi

Güngör, Dilek (2016), "Belediye Tahvili Geliyor", Sabah Gazetesi, http://www.sabah.com.tr/yazarlar/dilek-gungor/2016/12/19/belediye-tahviligeliyor

Gürses, Uğur (2010), “isçci Parasıyla Kalkınma!”, Radikal, 27 Aralık 2010, http://www.radikal.com.tr/yazarlar/ugur-gurses/isci-parasiyla-kalkinma-1034115/

Hazine Müsteşarlığı (1999), Niyet Mektubu, 9 Aralık 1999, http://www.tcmb.gov.tr/wps/wcm/connect/TCMB+TR/TCMB+TR/Main+Menu/Ya yinlar/Temel+Politika+Metinleri//MF+Niyet+Mektuplari

Hazine Müsteşarlığı (2000), Niyet Mektubu, 18 Aralık 2000, http://www.tcmb.gov.tr/wps/wcm/connect/TCMB+TR/TCMB+TR/Main+Menu/Ya yinlar/Temel+Politika+Metinleri//MF+Niyet+Mektuplari

Hazine Müsteşarlığı (2008), Niyet Mektubu, 28 Nisan 2008, http://www.tcmb.gov.tr/wps/wcm/connect/TCMB+TR/TCMB+TR/Main+Menu/Ya yinlar/Temel+Politika+Metinleri//MF+Niyet+Mektuplari

Hazine Müsteşarlığı (2017), Stand-by Nedir?, https://www.hazine.gov.tr/tr-TR/SikSorular-Listesi $? \mathrm{mid}=1003 \& \mathrm{~nm}=1003$

Hürriyet (2010), "Mali Kural Bu Döneme Yetişmiyor", 16 Temmuz 2010, http://www.hurriyet.com.tr/mali-kural-bu-doneme-yetismiyor-15333063

KTP (2017), “Türkiye'de Sukuk Piyasası", http://www.ktportfoy.com.tr/yatirimcikilavuzu/sukuk-kira-sertifikalari/turkiyede-sukuk-piyasasi.26.aspx

Maliye Bakanlığı (2004), Analitik Bütçe Sınıflandırması Eğitim El Kitabı (Ankara: Bütçe ve Mali Kontrol Genel Müdürlüğü).

Munyar, Vahap (2010), "Mali Kural Ertelendi, Babacan Çok Bozuldu”, Hürriyet Gazetesi, 17 Temmuz 2010, http://www.hurriyet.com.tr/mali-kural-ertelendi-babacan-cokbozuldu-15340011

Orta

Vadeli

Mali

Plan

http://www.resmigazete.gov.tr/eskiler/2005/07/20050702.htm

$(2006-8)$ 
Orta Vadeli Program

$(2009-11)$ http://www.bumko.gov.tr/Eklenti/28,20092011ovppdf.pdf?0

Orta Vadeli Program $(2016-8)$ https://www.bumko.gov.tr/Eklenti/9691,ortavadeliprogram20162018.pdf?0

Oyan, Oğuz (2016a), “Isssizlik Sigortasından BES'e”, Sol, http://haber.sol.org.tr/yazarlar/oguz-oyan/issizlik-sigortasindan-bese-180289

Oyan, Oğuz (2017), "Saray Holding A.Ş.", Sol, 7 Şubat 2017, http://haber.sol.org.tr/yazarlar/oguz-oyan/saray-holding-184766

Özelleştirme İdaresi Başkanlığı (2007), 2006 Yılı Faaliyet Raporu, http://www.oib.gov.tr/2010/dosyalar/2006faaliyetraporu.pdf

Sev, Kadir (2016 a), "Belediyeler Piyasaya Teslim", Sol, http://haber.sol.org.tr/toplum/belediyeler-piyasaya-teslim-tahvil-ve-sukukcikarip-borsada-islem-gorecekler-179701

Sev, Kadir (2016 b), "Zavallı Bütçe Yasası", Sol, http://haber.sol.org.tr/yazarlar/kadirsev/zavalli-butce-yasasi-178917

Sev, Kadir (2016c), "Kamu Kurum ve Kuruluşları Bütün Paralarını TL'ye Dönüştürecek", Sol, http://haber.sol.org.tr/toplum/kamu-kurum-ve-kuruluslari-butun-paralarinintlye-donusturecek-178280

T24 (2017), “Alsancak Limanı, Varlık Fonu'na Devredildi”, 10 Şubat 2017, http://t24.com.tr/haber/alsancak-limani-varlik-fonuna-devredildi,388158

Toker, Çiğdem (2016), “iktidar 'Örtülü' Harcamayı Sevdi”, Cumhuriyet Gazetesi; 15 Ocak 2016 ,

http://www.cumhuriyet.com.tr/koseyazisi/464671/iktidar_ortulu_harcamayi_s evdi.html

Toker, Çiğdem (2017), "Görev Zararı ve Şeffaflık”, Cumhuriyet Gazetesi, 21 Şubat 207.

Türkiye Büyük Millet Meclisi (2017), "III. Yılmaz Hükümeti", http://web.archive.org/web/20140915023729/http://www.tbmm.gov.tr:80/hukum etler/055.htm

Uygur, Ercan (2001), “Krizden Krize Türkiye: 2000 Kasım ve 2001 Şubat Krizleri”, Türkiye Ekonomi Kurumu Tartışma Metinleri, http://www.tek.org.tr/dosyalar/KRIZ-2000-20013.pdf

Wikipedia, 55. Türkiye Hükümeti, https://tr.wikipedia.org/wiki/55._Türkiye_Hükûmeti

$\star * *$

http://kararlaryeni.anayasa.gov.tr/Karar/Content/d18dab05-7549-4513-9ecedf4860a3ce10?excludeGerekce=False\&wordsOnly=False 